\title{
Correction to: Structural heterogeneity in and around the fold-and-thrust belt of the Hidaka Collision zone, Hokkaido, Japan and its relationship to the aftershock activity of the 2018 Hokkaido Eastern Iburi Earthquake
}

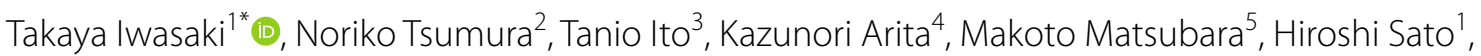
Eiji Kurashimo', Naoshi Hirata', Susumu Abe ${ }^{6}$, Katsuya Noda ${ }^{7}$, Akira Fujiwara ${ }^{8}$, Shinsuke Kikuchi ${ }^{9}$ and Kazuko Suzuki ${ }^{10}$

\section{Correction to: Earth, Planets and Space (2019) 71:103} https://doi.org/10.1186/s40623-019-1081-z In the original publication of this article (Iwasaki et al. 2019), the author name 'Matsubara Makoto' in author list is not correct. The correct name should be 'Makoto Matsubara'.

\section{Author details}

'Earthquake Research Institute, The University of Tokyo, Tokyo, Japan.

${ }^{2}$ Graduate School of Science, Chiba University, Chiba, Japan. ${ }^{3}$ Association for the Development of Earthquake Prediction, Tokyo, Japan. ${ }^{4}$ Hokkaido Research Center of Geology, Sapporo, Japan. ${ }^{5}$ National Research Institute for Earth Science and Disaster Resilience, Tsukuba, Japan. ${ }^{6}$ JAPEX, Tokyo, Japan. ${ }^{7}$ GEOSYS, Inc, Tokyo, Japan. ${ }^{8}$ Japan Oil, Gas and Metals National Corporation, Tokyo, Japan. ${ }^{9} \mathrm{JGI}$, Inc, Tokyo, Japan. ${ }^{10}$ Schlumberger Ltd, Doha, Qatar. heterogeneity in and around the fold-and-thrust belt of the Hidaka Collision zone, Hokkaido, Japan and its relationship to the aftershock activity of the 2018 Hokkaido Eastern Iburi Earthquake. Earth Planets Space 71:103. https://doi.org/10.1186/s40623-019-1081-z

\section{Publisher's Note}

Springer Nature remains neutral with regard to jurisdictional claims in published maps and institutional affiliations.

Published online: 26 March 2020

\section{Reference}

Iwasaki T, Tsumura N, Ito T, Arita K, Matsubara M, Sato H, Kurashimo E, Hirata N, Abe S, Noda K, Fujiwara A, Kikuchi S, Suzuki K (2019) Structural

The original article can be found online at https://doi.org/10.1186/s4062 3-019-1081-z.

*Correspondence: iwasaki@eri.u-tokyo.ac.jp

${ }^{1}$ Earthquake Research Institute, The University of Tokyo, Tokyo, Japan

Full list of author information is available at the end of the article the source, provide a link to the Creative Commons licence, and indicate if changes were made. The images or other third party material in this article are included in the article's Creative Commons licence, unless indicated otherwise in a credit line to the material. If material. is not included in the article's Creative Commons licence and your intended use is not permitted by statutory regulation or exceeds the permitted use, you will need to obtain permission directly from the copyright holder. To view a copy of this licence, visit http://creativecommons.org/licenses/by/4.0/. 